\title{
CULTURAL HYBRIDITY AND ITS COMPLEXITY IN ESMERALDA SANTIAGO'S ALMOST A WOMAN
}

\author{
Hibriditas Kultural dan Kompleksitasnya dalam Novel Almost A Woman
}

Karya Esmeralda Santiago

\author{
Ikwan Setiawan ${ }^{1}$, Linda Purwati ${ }^{2}$ dan Imam Basuki ${ }^{3}$ \\ $1,2,3$ Universitas Jember \\ ikwansetiawan.sastra@unej.ac.id
}

\section{Naskah diterima: 29 Mei 2020 ; direvisi: 19 November 2020 ; disetujui: 7 Desember 2020}

doi: https://doi.org/10.26499/jentera.v9i2.2495

\begin{abstract}
Abstrak
Tulisan ini mendiskusikan hibriditas dalam novel Almost A Woman karya Esmeralda Santiago. Novel ini menceritakan permasalahan kultural yang dialami Negi, tokoh utama, sebagai imigran Puerto Rico di New York, di mana ia harus mengapropriasi budaya Amerika agar bisa diterima oleh masyarakat induk. Untuk membahas permasalahan tersebut, kami akan menggunakan teori poskolonial Bhabha. Analisis tekstual digunakan untuk menjelaskan data terpilih dengan cara pandang poskolonial tanpa mengabaikan keterkaitan kontekstualnya dengan dinamika imigrasi dan diaspora. Hasil kajian ini menunjukkan bahwa tokoh utama harus menjalankan hibriditas sebagai strategi kultural untuk mendukung impian modernnya. Meskipun menikmati budaya Amerika secara apropriatif, ia masih berusaha untuk tidak melupakan budaya Puerto Rico. Dengan strategi ini subjek diasporik bisa menegosiasikan kepentingannya di tengah-tengah masyarakat induk dan kuasa budaya dominan, tanpa mengabaikan sepenuhnya budaya Puerto Rico.
\end{abstract}

Kata-kata Kunci: hibriditas, ketidakberumahan, mimikri, poskolonial, imigran Puerto Rico

\begin{abstract}
This paper discusses hybridity in Esmeralda Santiago's Almost A Woman. This novel tells about cultural problems experienced by Negi, the main character, as a Puerto Rican immigrant in New York, where she must appropriate American cultures in order to be accepted by the host community. To discuss this problem, we will apply Bhabha's postcolonial theory. Textual analysis is used to explain selected data from a postcolonial perspective without ignoring its contextual relationship with the dynamics of immigration and diaspora. The results of this study show that the main character must carry out hybridity as a cultural strategy to support his modern dreams. Despite enjoying appropriately American culture, she does not forget Puerto Rican cultures. With this strategy, the diasporic subject can negotiate its interests in the midst of the host society and the dominant cultural power, without completely abandoning Puerto Rican culture.
\end{abstract}

Keywords: hybridity, unhomeliness, mimicry, postcolonial, Puerto Rican immigrants

How to Cite: Setiawan, Ikwan, Linda Purwati dan Imam Basuki. (2020). Cultural Hybridity and its Complexity in Esmeralda Santiago's Almost a Woman. Jentera: Jurnal Kajian Sastra, 9(2), 115-146.

doi: https://doi.org/10.26499/jentera.v9i2.2495 


\section{INTRODUCTION}

Puerto Rican diaspora in the US has had a long history that could not be separated from the immigration process since the Spanish-Cuban-American War of 1898 and surged during the great migration after the Second World War to the contemporary era (Lorrin, 2015). Until the 1970s Puerto Rican immigrants experienced the problem of marginalization. Since the 1980s Puerto Rican diaspora has begun getting economic achievements and many educated individuals have been able to control the cultural representation of their communities. Their political role is even more significant, at least in presidential elections. Nonetheless, some crucial issues such as the use of illegal drugs and alcohol were still quite high among Puerto Rican youths until the millennial era (Ríos-Bedoya \& Gallo, 2003; Senreich, 2018; Szalay et al., 1993; Wurzman et al., 1982).

Another problem is their position as diasporic communities living in the midst of the host society with a dominant economic, social, political, and cultural position. Diasporic people have complicated problems in host countries, such as racial sentiment and the difficulty to practice new cultures that make them longing for various memories in their homeland and feeling unhomely, while, at the same time, appropriating some parts of metropolitan cultures (Král, 2009; Stock, 2010). Puerto Rican immigrants also experience racial and ethnic discrimination in various sectors of life (Araujo Dawson \& Suárez, 2018; Daponte, 1996; Gonzalez-Sobrino, 2018; Lobo et al., 2012; Rolón-Dow, 2010). Nevertheless, the immigrants also try to struggle over the progress of life by appropriating the cultural values and practices of the host community. This condition raises cultural in-betweenness for diasporic individuals. Many times, diasporic subjects make it difficult to delineate where one culture ends and another begins. Cultural identity, then, is no longer a fixed thing, but always in the process of negotiating, positioning, and becoming (Hall, 2003, 2013). However, ethnic, national, and transnational tensions experienced by diasporic people are often creative, even enriching a mother culture and often mobilizes collective identity, not only in relation to settlements or in respect of imagined, assumed, or native homeland, but also related to solidarity with members of the same ethnic group in other countries (Cohen, 2008).

Such cultural complexity is a creative source for writing diasporic literary narratives. Authors from the first, second, third, or later generations are the subjects of contestation, appropriation, prejudices, and mixed cultural expectations. Cultural complexity enables appropriating liberal values without completely abandoning mother cultures with conflicting processes, including redefining and re-understanding nationalism, multiculturalism, gender, 
and politics (Al Maleh, 2009; Ling, 1998; Moslund, 2010). In diasporic literature, the construction of cultural duality becomes a kind of "a must-be-presented menu," in which, between the memories of motherland and the necessity for adapting metropolitan society's cultures, the main characters from post-colonial countries are described as having problems of survival (Grace, 2007). Diasporic literature becomes a literary expression for negotiating immigrants' complicated conditions as a result of remembering various events in the motherland and getting racial treatment in a Western metropolitan city as well as having a dream of becoming more successful individuals through struggles and appropriation of dominant cultures.

One of the literary works which expose the cultural complexity of diaspora is a novel written by Almost a Woman (Santiago, 2012), first published in 1998. Santiago is a Puerto Rican-born American writer who most of her works portray the problems of Puerto Rican identity from the perspective and experience of an immigrant woman (Alves, 2012). This novel tells about the life of Negi, a young Puerto Rican woman who moved to Brooklyn, New York, following her mother who wanted to give a better medical treatment for her boy. As a diasporic individual, she encounters various cultural differences that make her facing some complicated problems. However, because she wants to become an actress, Negi, in the midst of serious difficulty for learning American cultures, including modern education, English, food, arts, and other customs, tries to create better situation day to day. At the same time, her mother wants Negi to keep preserving Puerto Rican cultures in the midst of her desire for becoming an American girl.

Some critics discuss cultural problems in Santiago's literary works. Almost a Woman explores the way a woman immigrant transgressing the communal and personal barriers of cultural identity by passing through a 'revolving door' that meanwhile affords her the opportunity to appropriate the host cultures while holding tight to the memories of and ties to her past (Salkauski, 2013). Negi serves as a model of how immigrant women may continue to value their personal experiences, all the while questioning themselves and reassigning a new meaning to personal identity. America's Dream is a literary product of Santiago's selftranslation to construct a hybrid postcolonial identity to regain her voices and to handle the marginalization of which she has been a victim (Sambolin, 2015). When I was a Puerto Rican is an auto-ethnographic narrative of a woman writer as the hybrid subject that constructs selfdiscourse in a transcultural space where differences in language and culture are the dominant events (Watson, 2013). However, a more complicated reading considers both When I was 
Puerto Rican and Almost a Woman as the narrative ways the memoirs portray the complicated interactions between Santiago's geographical locations, the changes in her understanding of class and ethnicity caused by displacements, and her dynamic attitudes towards the various communities both shaping her sense of self and being reshaped by her narratives (Echano, 2003). The two novels construct the renegotiations of identity by describing various communities-rural and urban Puerto Rico, economically deprived and upwardly mobile Puerto Ricans in the continent, and middle-class white America.

Although having a similar issue on immigrants' cultural problems, in this article we will focus on in-between subjectivity which produces unhomely condition, mimicry/mockery, and hybridity in the process of appropriating American cultures without abandoning Puerto Rican cultures completely. The narratives of cultural hybridity in Almost a Woman and its contextual condition as well as the author's critical vision are interesting to discuss. The main character experiences cultural encountering with the dominant white values and practices from which they should maintain a cultural appropriation. This issue enables the main character to produce a flexible strategy, particularly for playing subjectivity as an individual who is able for making a maneuver in the host country.

\section{THEORETICAL FRAMEWORK}

To discuss the problem, we will apply postcolonial theory (Bhabha, 1994). Bhabha's postcolonialism dismantles the binary opposition and criticizes a cultural complex as a product of ambivalent and in-betweenness in colonial and post-colonial times. Under the dominated conditions, a subordinate subject plays a strategy to negotiate their voices in the midst of cultural difference constructed discursively by the dominant. By having mimicry with continuous appropriation and inappropriate, the subordinate subject has the capacity of agency for entering the dominant power and modern culture; not quietly, still negotiating some original different culture. Cultural duality and slippage of the mimicry subject emphasize the uncertainty of cultural difference in post-colonial space; the surveillance function of the dominant toward the mimicry-subordinate-subject is disturbed because of the inappropriate and disavowal of cultural truth and dominant power. Mimicry is also mockery because the subordinate subject imitates modern culture, but this does not make them leave their mother cultures completely. The double vision of mimicry may become a menace for the dominant power because it subverts the unity and wholeness of master discourse and knowledge as the base of its power operation. Mimicry, then, becomes a strategic choice for 
the subordinate subject in order to survive in the midst of dominant groups that still consider them as the Other; disarticulating the voice of power as the form of agency.

When mimicry occurs in various representational products and ordinary practices that disturb the wholeness of knowledge construction as the base of power operation using binary opposition framework, its further implication is the absence of pure or authentic culture and the emergence of hybridity. However, hybridity is not merely discourse or practice of crosscultural mixtures - such as in assimilation, syncretism, or creole. Instead, it brings some politico-cultural dynamics experienced by the colonized or ex-colonized subject. As a product of mimicry-mockery in double articulation, hybridity enables the hybrid subject's perspective, behavior, and discourse in re-understanding the claim of the difference of epistemological truth as the base of domination. Indeed, by having a hybrid identity, the subordinate subject is under the easier control of the dominant because he/she seems to follow and practicing the dominant culture. However, such hybridity is a disavowal of discriminatory-based-power, because she/he can multiply her/his subjectivity and culture. In hybridity, a negotiation of local/mother culture still occurs from which the resistant power amid ambivalence and deception of recognition still exists. Dominant cultural aspects are appropriated no longer as the symbol of authority, but as the sign that may produce new slippage meaning and, further, may destroy the foundation of cultural difference essentially. While the dominant group considers the subordinate one, hybridity may become a cultural strategy to deceive meaning desired by the dominant.

Indeed, for the Latin American context, postcolonial studies have a different particularity from the perspective developed by Bhabha. Latin American thinkers were less interested in postcolonial ideas developed by Said, Spivak, and Bhabha because they put more emphasis on the textual aspects of literature and language (Vieira, 1999). For many Latin American thinkers, decolonization has become an academic and practical effort to dismantle and resist the exploitative legacies of European and US colonialism and its transformation into globalization and neoliberal capitalism in Third World countries such as Latin American countries (Mignolo, 2007b, 2007a, 2011, 2020a, 2020b; Mignolo \& Walsh, 2018). Decolonialization perspective is also brought into literary studies by making literary works produced in Latin American countries as their material objects to reveal decolonial discourses and strategies to dismantle colonial-Eurocentric influences as well as to construct literary knowledge that articulates the socio-cultural characteristics of Latin American societies 
(Ramos \& Daly, 2016). Even if there are those who share the issue of hybridity, the material object prioritizes the social basis of the cultural process (Aboul-Ela, 2004; Canclini, 2005).

However, Bhabha's postcolonialism can be used to examine cultural issues in Almost a Woman with some considerations. Puerto Rico was colonized by Spain until 1898 and from 1898 to 1952 became the territory of the US Commonwealth, so that they experienced not only economic and political influence, but also cultural influence, both Spanish and American cultures (Hernández-Acosta, 2017). Migration to the mainland (the US), have made Puerto Ricans increasingly accustomed to appropriating American cultures, although they still have faced some problems of racial identification, citizenship, and belongingness (Ramos-Zayas, 2007; Vargas-Ramos, 2014). The cultural problems represented in this diasporic novel intertwine with such reality, because the main character and her family also migrate to the US with the hope of getting a better life even though they have to carry out cultural strategies to survive in the midst of metropolitan society. So, as a diasporic novel, Almost a Woman offers narrative events that bring a discourse of Puerto Rican immigrants' struggles in the host society with its metropolitan values and the way they should negotiate local cultures. Therefore, Bhabha's concepts on mimicry, mockery, and hybridity, as commonly used by many researchers of diasporic and postcolonial literature-including by Indonesian researchers (Furqon \& Busro, 2020; Suwondo, 2014; Tallapessy et al., 2020)—are strategic perspectives to analyze the problem.

\section{METHOD}

Bhabha's theoretical perspectives will contribute to the whole analysis of primary data from Almost a Woman. The primary data of the novel are related to the issues of cultural problems experienced by the diasporic characters. A critical-textual method will be conducted to analyze some characters' statements, dialogues, settings and characters descriptions, conflicts, and other narrative elements. This analysis aims to explore the construction of diasporic subjects' cultural problems living in the midst of different host society and the process of mimicry/mockery and hybridity as a cultural strategy. For having critical understanding, a dialectic method will be conducted by juxtaposing the dominant discourses of cultural hybridity in the novel with the discourses of the diasporic Puerto Rican life condition and problems in the US from the appropriate secondary data. The result of the dialectic reading - a textual-contextual mode - and information related to the author 
contribute significantly to know her critical visions in responding and incorporating the life of diaspora as well as the ideological perspective she offers through the novel.

\section{RESULT AND DISCUSSION}

\section{Feeling Unhomely in the Host Society}

Almost a Woman describes the migration of Puerto Rican family into the US. Just like many other immigrants who have their own reasons to move from their countries to new places, Negi's family also has a particular reason to move to the US. Mami, Negi's mother, wants to seek medical care for her youngest son, Raymond. His toes were nearly severed by a bicycle chain when he was four. In Puerto Rico, doctors wanted to amputate the often red and swollen foot, because it wouldn't heal. In New York, Mami hopes the doctor could save it (Santiago, 2012, p. 1). The choice to bring Raymond to the US represents the assumption of Third World people that advances in science and technology, including for health matters, remain the property of First World State. The comparison made by Mami also indicates that the discourse of American superiority is constructed at the beginning of this novel. The discourse of the American dream has encouraged many Puerto Ricans and other Latin Americans to flock across borders from the 19th century to the new millennium.

Coming into the host community always raises complicated problems. The differences in environmental, human, and cultural conditions are a burden for the diasporic subject. Negi feels a contrast between Puerto Rico's rural environment and Brooklyn, New York, because the American situation is completely different from the children's comics she read. Negi and her family have to experience the harsh and frightening everyday conditions of Brooklyn. For her, New York is not as beautiful as she imagined, but a dark city that made her disappointed and doubted her hopes (Santiago, 2012, p. 1). This is a pre-condition of more complicated problems as commonly experienced by immigrants. Negi begins wondering whether America is not a place that she has expected before since it is unbearable, contrasts with the trim horizontal suburbs of white American that she admires in children's comic book. For Negi, entering a new place and situation is difficult because she has never been in the US, and what she is attempting to incorporate is merely her fantasy of what America would be like.

In Brooklyn, Negi also experiences anxiety and fear because of insecure social conditions. Many gangs and criminals could at any time endanger her life. 
"Something could happen to you" was a variety of dangers outside the locked doors of our apartment. I could be mugged. I could be dragged into any of the dark, abandoned buildings on the way to or from school and be raped and murdered. I could be accosted by gang members into whose turf I strayed. I could be seduced by men who preyed on un-chaperoned girls too willing to talk to strangers. (Santiago, 2012, p. 5)

Negi feels discomfort and insecurity with the dangerous condition in Brooklyn. It is the first stop for immigrants when they come into New York where many dangerous gangs and crimes are common. They make Negi has less freedom than she had in Puerto Rico because she is aware of the danger around her. Such narrative produced at the beginning of the novel becomes a discourse of dangerous criminalities in the area of immigrants. Distrust and hostility among people also contribute a lot to the marginality of ethnic minorities (Weigui, 2016). This phenomenon is frequently experienced by immigrants because of the ethnic threat which occurs in the US. Public discourses in American society construct a close relationship between immigrants and crime (Menjívar \& Bejarano, 2004; Sohoni \& Sohoni, 2014).

As an individual who has to live in the host society, Negi, tries to adapt to various American cultural values and practices. However, the process is not easy because of the different habits and orientations. She feels neglected by the host society which affects her low self-esteem. This makes her hard to mingle with her surrounding and, further, makes her feeling alienated. Because of this condition, Negi longs for her homeland which triggers her nostalgic feeling. As represented in the first chapter of the novel, the nostalgic feeling towards her mother's country occurs when she finds it difficult for being accepted by the host society.

Memory in the motherland becomes the dominant element to recall when she feels unhomely in the US. Comparing her birthplace in Puerto Rico, Macun, to where she is now, Brooklyn, is one way to celebrate a nostalgic feeling.

Mornings, on my way to JHS 49, I yearned for my life in Macứn. I missed the dew-softened air, the crunchy gravel of the dirt road, the rooster's crow, the buzz of bees, the bright yellow sun of a Puerto Rican Dawn. I resisted the square regularity of Brooklyn's street, the sharp-concerned buildings that towered over me, the sidewalk spotted with crusted phlegm and sticky chewing gum.

(Santiago, 2012, p. 31)

Negi describes the shape, scent, and color of Macun in detail. This attention to detail in the depiction of scenery is characteristic of the nostalgic use of landscape. The use of different senses in the depiction of the landscape as a particular post-colonial implement (Ashcroft, 2001, p. 127). The overpowering inclination of visuality is a characteristic of western culture, and thus using different senses in the expression of their creativity, post-colonial or diasporic authors can differentiate themselves from metropolitan writers. The use of senses can also be 
seen as a form of empowerment for the subordinate diasporic subject. Hence, Negi experiences disillusion as the effect of her nostalgic feeling, especially upon her father and homeland. She wants her father to be there to bring her back to Puerto Rico. Negi brings back memory when she, her mother, and Raymond were still on the island. This unhomeliness creates a sense of duality which positions the homeland and all subjects in it as the ideal things to remember because the host country still gives no warm condition. The prior time in Puerto Rico is the best memory that she wants to come back anytime she has a problem.

Her nostalgic feelings and longing for homeland become apparent; as she describes that she wants to return to a rural place, Macứn (Santiago, 2012, p. 39). Homeland is a part of cultural identity and leaving it means missing various events that construct her identity. Therefore, being able to reunite with her homeland becomes a tremendous source of joy that she wants to feel. The descriptions of the homeland and its natural imagery in the novel represent nostalgia, which is also closely linked with the concept of displacement. Nostalgia occurs when memory and history refract each other. It enables the diasporic subject to explore the network of power relations within which they have been caught in the modern world, and beyond which it often impossible to move (Walder, 2012).

Remembering the homeland also produces sadness related to a particular problem. In Negi's case, the divorce of her parent produces negative energy that haunts her mind and imagination. This reality doubles the psychological problems experienced by the diasporic subject when she does not feel homely in American society. Thus, idealizing the past is often a project of imagination that clashes with bitter reality, even though there is happiness that can be reconstructed. Negi thinks that she will not face difficulty and still has a comfortable life in Puerto Rico if her parents are still together (Santiago, 2012, p. 31). Negi is emotionally dislocated from the comfortable home of her father who did not want to follow her mother to New York. She keeps longing for her homeland as the real home. In this case, she feels unhomely.

A home is a comfortable place of desire in the immigrant's imagination. Home is not merely a physical structure of a building, but it "functions as a repository for complex, interrelated and at times contradictory socio-cultural ideas about people's relationship with one another, especially family, and with places, spaces, and things" (Mallett, 2004, p. 84). Negi's psychological condition appears to be a comfortable place in her un-homed condition. Being un-homed is not the same as being homeless, but it is not feeling at home even when we are in our own home because our cultural identity crisis makes us a psychological refugee (Tyson, 
2006). This unhomely condition leads to Negi feeling nostalgia toward her homeland and getting alienated in the midst of American society. She is suffering and regretting her decision to follow her mother but she cannot do anything except accepting this situation. It also shows that Negi lives between past and present because she feels that the previous life is much better before she moves to New York.

Negi imagines her father's life in Puerto Rico. Yet, the fact that her father has already married another woman and moved to the place which she does not know makes her disappointed with him because he did not even consider her mother's feeling. She could not accept the fact that her father decides to start a new life with another woman. Those situations affect her psychological conditions in dealing with her past (Santiago, 2012, p. 31). The problem, furthermore, makes Negi re-evaluating her cultural heritage and the ways in which these factors affect her future in the US. Her father is a signifier of her engagement with people, nations, and cultures. Since his father has a new family, she feels a change in family ties in which harmony is only a memory. In her mind, Negi begins rethinking the meaning of being a Puerto Rican, when Papi and all of her relatives are no longer the presence awaited at her home in Brooklyn. Although Negi has no political trauma, the absence of Papi in her life is a problem. For diasporic subjects, the problem does not only relate to the loss of family bound but also relates to the courage to evaluate the connection with the motherland and its people. Why? It is because in her homeland many people make her sad. Memories about the homeland may still be there, but it is no longer complete.

When her homeland is no longer the dominant orientation, Negi begins opening her mind to learn and understand American cultures. Her current life gradually encourages Negi to learn what is needed as an immigrant in the midst of American society. When Puerto Rican culture is no longer a dominant existence in her mind, the old identities and memories from the past are not a barrier to accepting and absorbing new cultural values and practices. Moreover, Negi tries to appreciate her new life in New York because of the opportunity and the promise of a better life.

\section{Mimicking and Appropriating Host Cultures}

Making a survival strategy in the midst of American cultural diversity is needed. In this case, language plays a significant role to survive because it is a tool to learn and absorb social values in the host society. In the beginning of her life in the US, Negi faces some difficulties because of her poor English. She, for example, gets language discrimination from her school 
friends because of her inability to communicate in good English. Administratively, it almost makes her backs one grade due to her poor ability to speak English. For all immigrants who want to live in the US, English language skills are an absolute requirement. Values, lifestyle, and actions that are in accordance with consensus can only be learned in school and everyday life through English language skills. This condition makes her eager to improve her English skill both in oral and written skills. The ideal orientation for being accepted by white Americans doubles her enthusiasm to improve her English from time to time, wherever she is. She even stops at the library every day after school, reading and memorizing the words that go with the pictures in the oversized pages (Santiago, 2012, p. 17). She starts the lesson by reading an easy and simple book such as alphabets books where she can learn through the illustrations. Then, she looks up the word if she does not know the translation, and then she imitates how it is spoken.

English skill was one of the common problems for many Puerto Ricans who come to the US. In 1930 the US government demanded that English should be the official language to be taught in schools (Pousada, 2008). The condition of the language dilemma was very hard for Puerto Rican immigrants who commonly speak Spanish. The importance of English makes Negi and her sister also practice English at home (Santiago, 2012, pp. 17-18). They often mix Spanish and English when they talk at home. The hard work shows that Negi really wants to become a part of American society. She believes that by learning English she will have a good chance to know American society and cultures more. Further, American-English will give her many opportunities and become a door of new cultural experience as well as empower her in the construction of knowledge. Thus, learning English is appropriation as a diasporic subject's survival strategy. In the US, a newcomer who wants to study is required to be proficient in English as one of the educational requirements. Success in getting a good education can help diasporic individuals to gain dreams. Many Puerto Ricans migrated to the US because they believed that they would find better jobs and education than on the island. Unless one could not speak English, they will not be able to get the best education in the US (Fuentes, 2020).

Nonetheless, when Negi finally can speak English fluently, she still finds a new difficulty because of her accent. In her new school, Manhattan Performing Arts High School, non-standard speakers are ignored by white Americans. Their contributions are reduced from language to mere noise. The ones who cannot eradicate their accent are discredited about their speech and considered not worthy of time to have listened. They think that non-standard 
accent speakers like Negi are not using proper English because they just translate the language based on its structure. It emphasizes the idea that her speech is defective. Her teacher also thinks that if she cannot even articulate herself correctly, she cannot possibly have anything to contribute that is worth to listen.

Accent eradication was important, we were told, to widen the range of parts we could play. An actor must be versatile enough to change the way he or she spoke to fit the character being played. The standard speech laid the foundation for other accents, including, if necessary, the one we had when we first walked through the doors of performing Arts High School. (Santiago, 2012, p. 68)

It is tied up in and contributes to a bigger problem when regional and international accents of English are mocked and derided. The correct accent, critically, can be read as a signifier of white American superiority that determines the life and the future of the diasporic subject. One can be less likely to get a certain job is not merely about intelligence or suitability, rather than because of her accent. Because of her practical interest, Negi needs to change her Puerto Rican accent. She believes the stigma about her own accents to the point where she does not feel confident with the way she speaks. In this case, eradicating accent is one way for Negi for being accepted in her school. Nevertheless, doing so, makes her gets easily controlled by the host society because she seems to follow their way of speaking.

Every individual has an accent that represents and identifies race, national origin, profession, and socio-economic status (Matsuda, 1991). However, immigrants may encounter a barrier of accent discrimination in which their accent as the signifiers of national origins should not be shown in order to get acceptance in a new place and to avoid discrimination and, even, racialization in a country with multiculturalism (Goode, 1998, pp. 44-45). In the context of the US, this problem is one of the impacts of implementing the English language policy. Since 1980s, many states in the US, especially the largest "immigrant-receivingstates", have established and adopted English-Only law in various levels of the U.S. political system and the private sector when the issue of immigration has been of high national salience (Liu et al., 2014) with a political argument that "using foreign languages threatens unity within the US" (Aka \& Deason, 2011, p. 292). In addition, the common ideal discourses behind this policy is that immigrants will have good earnings in the US proficiency (Hwang et al., 2010; Zavodny, 2000; Zhen, 2016) and experiece social mobility (Reierson \& CeledónPattichis, 2014) if they have English proficiency. Despite the growing resistance to this policy, the US government has been developing English language learning (ELL) for immigrants, especially their children, so that it will be easier for them to integrate into American society (Bennett \& Jaradat, 2011; DaSilva Iddings \& Katz, 2007; Stufft \& 
Brogadir, 2011). This proces, further, will make English becoming hegemonic ideological apparatus among immigrants (Miller, 2009).

The discourse of the English primacy which is recognized as a regime of truth by Negi and her sibling indeed becomes problematic when associated with historical reality where this language was the official language used by the US government to colonize Puerto Rico after the invasion in 1898. The US government formed a military government to run the capitalistic agricultural industry in authoritarian rule (Clachar, 1997, pp. 107-108). Many American businessmen invested in the agricultural industry, thus marginalizing local landowners. Capitalistic industrialization makes many workers and farmers lose their jobs. This condition prompted the exodus of immigrants to the United States in the 1930s to 1940s. In the US they had to learn English, like the way white people used it. However, what Negi and her sister do is not to establish the position of English as the language of the colonizers. Instead, the power of this language is used to struggle over their interests and goals in the US. Their mimicry, thus, eliminates the power of English as a colonial language, but merely serves as a signifier whose meaning is invested with new meanings in accordance with the interests of the diasporic subjects.

Not surprisingly, for most first-generation immigrants or parents, English is considered to be able to marginalize Spanish. That was also felt by Mami. As a representation of the authoritative subject that still believes in and wants a sustainable mother culture, Mami doesn't like it when her children prefer to learn English at home. This difference gave impact when Negi watched an English language television program, Mami was quite worried (Santiago, 2012, p. 18). This different view emphasizes binary opposition between parent and child in positioning English. For diasporic parents, English will damage their mother tongue and culture, while for children it is the key to success. The contradictions between maintaining tradition and realizing progress in the direction of Western culture do often occur between the young generation and the older generation of diaspora.

The cultural tension between Negi and her mother intertwines with the majority of Puerto Rican immigrants families in the US. Immigrant children adopt English and American culture more quickly than their parents. This raises a problem because their children, especially those who are already working, have become more liberal, resulting in frequent conflicts with parents who still believe in traditional values (Rendon, 1974). For Puerto Ricans who were born on the island and migrated to the US, the issue of identity has become more complex. Historically, Puerto Rican cultural identity has been constructed from various 
elements, including the process over the centuries to become a colony of Spain as well as the invasion and occupation by the United States (Guzzardo et al., 2016). For those who migrate to mainland, the US, they face more complicated cultural and linguistic problems because of their status as immigrants, in addition to their will and sentiment towards Puerto Rican culture. Maintaining the mother tongue is an effort to maintain local culture in the excolonizer country. Therefore, the majority of Puerto Rican families in the US still use Spanish in everyday conversation, even though their children learn English (Urzúa \& Gómez, 2008). Mami's home is a geo-cultural space where language as an identity marker must be used and maintained. Meanwhile, for Negi, learning English for the betterment of life can be done anywhere, even at home. The different view on the language between Mami and Negi, further, shows that mimicry does not only change the cultural reception of language but also problematizes and criticizes the dominant ideology that accompanies them. However, for Negi, linguistic mimicry has a different goal; to achieve her ideals in modern ways of life.

Negi's struggle to be a part of American society is not easy. As a newcomer, she does not know about American cultures in detail. She, then, tries to find guidance from her friends, but she does not have anyone who can help her to know more about American cultures. In this stage, media become the important objects to learn particular cultures and give impact for the young people (Valkeburg \& Piotrowski, 2017). The existence of celebrities or characters in popular media, for example, can be a role model that influences their vision. During the process of cultural learning, Negi looks the ways to define herself as a part of society. The comic is a medium she uses to learn about the US. Through its character, Negi starts to know how to be a common American teenager. Most of the American teenagers spend time by playing game and hanging out with their fellows without considering homework and school. In this case, this condition is depicted from the life of Archie, an outstanding comic character (Santiago, 2012, pp. 26-27). From Archie, Negi finds various discursive constructions of becoming American teenagers. She learns from the comic's characters because there are no Americans in her neighborhood. In general, immigrants from Puerto Rico and other Latin American countries will inhabit special areas, so that they speak Spanish every day. Archie, Veronica, Betty, Reggie, and Jughead are the comic's characters that represent American teenager's life style. Negi often feels jealous to Archie and friends because their only responsibilities are to look trendy and to keep their boyfriends and girlfriends happy. This makes Negi desires to be a common American like them. Even though the fact remains that she has a mother that controls the way she behaves in the US. She begins comparing her life 
with Archie who lives in a world with no parents, making his decision without consulting anyone but himself while her life is defined by an obligation as a student and elder sister.

In the next stage, Negi experiences cultural encountering which disrupts her belief in the value system and social practices she accepted and practiced in Puerto Rico. There, students are not permitted to wear a mini skirt and makeup at the school. However, in the US, students are not so restrained by cultural and moral behavior.

Every morning on the way to school, Yolanda and I ducked into the door way of an apartment building on Bushwick Avenue and rolled up our skirts to the length other girls wore theirs. We drew lines around our lids with an eyebrow pencil stolen from Yolanda's mother. In school, the girls who took pity on those of us whit old-fashioned mothers often shared their lipsticks and rouge and help us tease our hair into beehives sprayed stiff. (Santiago, 2012, p. 28)

Negi imitates the way American high school students wearing mini skirt and make up as common culture based on the freedom to express their desire of dressing. This academic fashion style is a part of American liberalism which guarantees individuals' desire. Negi is aware that she can survive in the host society only by mimicking the way her friends behave. Mimicking how to dress and lifestyle is an appropriation done by the diasporic subject so that she can mingle into and be accepted by the American youth community. The process is important for a diaspora community because when they still maintain fashion from their homeland, the dominant group will continue to differentiate and consider them as the Others. Of course, these conditions can complicate their life. The popularity of mini skirts as school uniforms cannot be separated from the fashion trend. Mini dress fashion with a skirt above the knee was introduced by Mary Quant in London in the 1960s and immediately became a trend in the United States and other European countries (English, 2013, pp. 92-94). Until now, mini skirts are still a popular outfit for American and European students.

Make-up and wearing mini skirts can be read as a shift in cultural orientation as a result of mimicry carried out by Negi. We can see the construction of liberalism discourse that prioritizes individual freedom in expressing oneself as guaranteed by the constitution. The diasporic subject finds new value and practice that give hope for new achievements for young people their age. The freedom to dress up and makeup is also an opportunity to experience the freedom of expression as experienced by American youth. Of course, this practice is contrary to Puerto Rican traditional values in which teenage girls are prohibited from wearing make-up and mini clothing. To the extent, when spending hours to practice using makeup, Negi has to trick Mami by saying it as homework (Santiago, 2012, p. 82). This action may seem not important event, but it shows the courage to lie in order to realize her desire to become an 
American teenage girl. The desire to be part of a dominant culture enables her to marginalize Puerto Rican cultural authority represented by Mami. However, the strategy must be done in order to familiarize her with liberal values that will contribute to the achievement of her ideals.

Not only in terms of language and fashion, but mimicry is also carried out by Negi and her sisters in matters of culinary culture. Food is not only related to the taste and deliciousness of dishes, but, in a more critical understanding, it becomes an important part of cultural identity and nationalism (Ichijo \& Ranta, 2016). Therefore, Mami does not want to completely exclude Puerto Rican food in dishes for her family. Moreover, Puerto Rican food is also beneficial for their children's health. American food is served at certain times as the type of food of the host community so that their children are not embarrassing when they are invited to eat by their American friends (Santiago, 2012, p. 24). Mami practices mimicry to appropriate new culture, without negating mother culture which still gives benefit. Even though traditional food is only served in the dining room, at least, Mami can connect their children with Puerto Rican culture. She also prepares her children with American food as a strategy for living with the host community. Although she lives in the new place, it does not mean she leaves her mother's culture completely.

Although Negi and her sister prefer American food, they cannot refuse Mami's desire to consume traditional Puerto Rican food. Even though Negi is Americanized for most of her life, Mami still accustoms her to not being completely separated from Puerto Rican culture. Not surprisingly, in every monthly shopping, Mami always buys Puerto Rican special ingredients, such as huge sacks of white rice, beans, cans of tomato sauce, onions, garlic, green peppers, fresh oregano, recao for the sofrito, Bustelo, sugar, and evaporated or powdered milk (Santiago, 2012, pp. 61-62). For Mami, the presence of Puerto Rican food is a material link that connects her family to cultural heritage and local community because they do not have many chances to consume it frequently. Therefore, food can be a useful tool for immigrants to maintain their cultural identity and connectedness with their community as well as gives a sense of rootedness of homeland.

Moreover, local Puerto Rican food is influenced by cultural diversity and rural lifestyles in which culinary influences can be found in Spain, Africa, Taino, and America (Rodriguez, 2013, p. 1). Luckily, in the US, immigrants can still buy Puerto Rican special food ingredients easily, so they can still feel the culinary atmosphere like in the homeland and find the meaning of home in the host community. The role of specific regional food in the 
dislocation is highlighted as particularly important. Sensorial and emotional experiences provoked by the smells, noises, colors and signs present in immigrant shops are powerfulmmemonic cues (Holtzman, 2006). Food is a reminder of the homeland and constitutes an important aspect in the consumption experience because it comprises a set of products and actions that reflect the culture, values, identities, and ethnicities (Garzone, 2017, p. 214). Consuming familiar food may provide the possibility of being transported to the whole world of home (Sutton, 2001). Such emotional geographies of displacement are an important part of how immigrants experience daily life and construct their diasporic selves. Through tastes and aromas, Puerto Rican foods create spaces where home can be re-created under diasporic circumstances which may cause homesickness.

No matter how ideal the local food functions for immigrant parents and no matter how strong they maintain it, their children have a culture that is unlikely to bring them back to authentic culture. This in-between space becomes the place where Negi and her sister find themselves in cultural tensions where two great powers draw them in dynamics, although often lead to conflict. However, public activities encourage them to prefer American food (Santiago, 2012, p. 62). In this process, a redefinition of the subjectivity of diasporic individuals occurs in which Negi cannot longer return to mother culture absolutely, even though Mami continues to present and negotiate it. The will to think and behave like as American youth mostly make Negi prefers to liberalism as the dominant reference. Even so, the presence of the authority, Mami, makes it still connects to the homeland and its distinctive culture. The presence of some Puerto Rican terms relates to food in Almost a Woman, further, can be read as a strategy to include local/national language in the midst of using English for writing the novel (Vidal Claramonte \& Faber, 2017).

\section{The Complexity of Hybridity}

Indeed, when mimicry occurs in various representational products and ordinary practices that disturb the wholeness of discursive and knowledge construction as the base of power operation using binary opposition framework, its further implication is the absence of authentic culture and the emergence of hybridity. Ideally, hybridity would enable diasporic subjects to enjoy and position themselves in the in-between space where they can transcend the binary opposition-based-power, as well as evaluate themselves and authentic culture. They can experience the host culture while simultaneously a part of the mother culture as a survival strategy. 
However, Mami's authentic cultural orientation that is transferred into Negi's life engenders a complicated socio-psychological process. Although Negi likes Americanism she cannot completely ignore her Puerto Rican background because Mami-as the representation of partial traditional authority-always reminds her to keep maintaining some mother cultures, including belief in superstitions and myths.

'Ay, no! Don't get black' Mami had recently rid herself of mourning clothes. She was afraid that if she kept them, they'd bring bad luck. When I suggested she burn them, she flinched and I understood that fire implied bad things for poor, dead, Fransisco. If she gave the clothes to someone not in mourning, they'd bring the recipient bad luck. So, that the bad luck in them wouldn't escape, and put them out with the garbage. (Santiago, 2012, p. 110)

Superstition for liberal individuals is something irrational, but for Mami it is important. Mami suggests Negi not to buy black dress because it brings bad luck. Red clothes are also refused by her grandmother. She claims red clothes bringing on hard life period and heaven forbade on a woman of childbearing. Negi is still forced to believe in this myth although she is not pregnant. Mami and Grandma's belief in myths - and also their love of food and other aspects of Puerto Rican culture in the midst of hard life in the US-represent a desire to strengthen a discourse of authenticity that still grows strongly among Puerto Rican diaspora, especially those born and experiencing life to adulthood in the island. They identify themselves as "islanders" and name those who were born or have been living since childhood as US "mainlanders". The cultural authenticity of "islanders" emphasizes the belief and willingness to practice Puerto Rican culture as a form of their connectedness with the motherland even though they also enjoy life in the US (Ramos-Zayas, 2004). Meanwhile, "mainlanders" are positioned as subjects who assimilate with American cultures so that they cannot be considered authentic anymore. The love of authentic cultures is actually a form of, in Spivak's term (Morton, 2007, pp. 126-127), a strategic essentialism to negotiate local subjectivity in the midst of American cultural hegemony so that they do not lose solidarity among fellow immigrants. In this context, immigrant mothers in the US have a strategic role to continue socializing Puerto Rican culture, both through family activities at home and social activities such as in cultural festivals (Umaña-Taylor \& Bámaca, 2004).

However, not all Mami and grandmother's advice give significant impact on Negi, because she already believes and practices some of American cultures which lead her to have a realistic mind. Negi does not believe in superstition because it is irrational. Being an ideal daughter, the rational answer is very important for Negi. Yet, she does not against her mother's way of thinking as a part of Puerto Rican culture. Indeed, Negi does not resist 
against Mami's will at home directly, because she still appreciates her as the authoritative subject. Nevertheless, as a result of social interaction and liberalism she believes in, Negi often undergoes actions that are contrary to social norms in Puerto Rico but are normal for young Americans. At the age of 19, for example, Negi had love affairs with some men. She became completely obsessed with and allowed herself to be controlled by a man. She dated many men much older than her though her mother did not let her date.

When she decides to date many men and ignored his mother's words, Negi is actually getting used to the tradition of young Westerners in interpreting love. Her mother's ban is both the voice of family authority and Puerto Rican values, which considers premarital dating wrong. Among Latin there is an ideal view that women must maintain their virginity to the level of marriage and women who are sexually active outside of love relationships (Wright, 2014, pp. 248-249). Therefore, many parents of Puerto Rican immigrants in the US send teenage girls to the families or relatives in Puerto Rico so that they will not fall into promiscuity (Pérez, 2002, pp. 39-40). For Negi, sexual freedom must be celebrated and enjoyed without having to heed traditional restrictions in mother culture. This discourse of sexual freedom becomes a dominant issue in many diasporic literary works because it becomes a discourse and practice of stereotype that distinguishes from tradition in the origin countries.

However, this does not mean that as a young Puerto Rican woman, Negi completely ignores and abandons Puerto Rican cultures. She has gotten cultural lessons from Mami and her grandmother, so that, even though she has been forced to, Negi also has an understanding of mother culture and motherland. Life in Puerto Rican enclave also raises her bond to some of Puerto Rican cultures. This discursive reality can also be found in the lives of Puerto Rican youth in the US, where, despite being accustomed to American traditions, they still have solidarity with the homeland so that they are not a fully part of American political and cultural society (Estrella \& Kelley, 2017).

What is interesting to note is the fact that no matter how much white cultures are carried out by Negi, she is still seen as the Other and can never be a whole part of white community. Her supervisor's astonishment at the performance school when he found out she does not have Puerto Rican accent made her feel offended.

More than once I was told I didn't "sound" Puerto Rican. 'You don't have an accent,' Mr. Merton, one of the supervisors, remarked, and I explained about performing arts and standard speech. When he implied that I didn't "act" Puerto Rican, I swallowed the insult. 'Maybe you haven't met enough of us,' I suggested, hurt that he was surprised Puerto Ricans could be competent, chaste girls who spoke good English. (Santiago, 2012, p. 68) 
Her attempts to speak English with an accent like white American - and other efforts to appropriate the culture of young Americans - are not a simple struggle. Meanwhile, in the performance school, accent accuracy is one of the requirements that must be met in order to be fully involved in the learning process. So, when Mr. Merton expresses his astonishment, it was tantamount to saying that true Puerto Rican citizens are not worthy of being able to speak and be cultured as white people did. Of course, Mr. Merton hooks up with the authority and majority of American white people who saw immigrants as a social and cultural problem. Until the early 2000s, for many white Americans, Puerto Rican immigrants were associated with racist stereotyping such as laziness, ignorance, crime, and other uncivilized habits, all of which were attached to their underclass position (Oropesa et al., 2008, p. 1318). Such discourse is a form of classification of the Others that contributes to discrimination in socioeconomic actions such as education and wages.

For Negi, the identification for behaving more like American than Puerto Rican means confronting the new problem. Losing her Puerto Rican accent does not make her instantly being accepted by the host society. In a practical sense, as an immigrant-student of performing art, her English accent benefits her. But, in a cultural sense, it still produces a racial sentiment. This ambivalence of metonymy actually becomes a self-reminder and creates, what we call, a 'post-colonial ethical awareness' in which a diasporic subject from excolonized land should have an appropriate strategy and a critical understanding in the midst of mimicry and hybridity they have done because the Othering process still exists in the midst of liberal metropolitan practices. Although the Western people have constructed and considered themselves as democratic subjects, their belief in superiority often have been corrupted some ideal discourses as equality among human beings when they have faced with ex-colonized people from Third World countries.

That ethical awareness also enables Negi making a critical reading of stereotyping directed at Hispanic or Latino women. On one occasion after watching a film, West Side Story, for example, she gives critical comments. In the film, the only virgin, Maria, is played by an American artist. Meanwhile, the sexy spitfire was always performed by Puerto Rican.

'It's not just a movie,' I argued, 'it's the only movie about Puerto Ricans anyone has seen. And what's the message? White Puerto Rican girls dangle from fire escape singing sweet tunes to Italian guys, while dark-skinned Puerto Rican girls sleep with their boyfriends.' (Santiago, 2012, p. 121) 
West Side Story is a musical film directed by Robert Wise and Jeremy Robbins (1961). The story of this film resembled Shakespeare's Romeo and Juliette tells about a conflict between the white gang and the Puerto Rican gang with a love problem in it. This film was quite popular in its day and became one of the films which were quite significant in the history of American popular culture. However, in this film there are racial issues that are quite sensitive about Puerto Rican community in the US which are described as subalterns related to various social problems (K. Brown, 2010; Davine, 2016). Exposing the film in the novel is an entry point to produce a discourse of ethical-critical awareness to resist the commonideological construction of Latin people and culture in American popular cultures and media. Various American popular cultures and media produce Latin people in racist construction which positions them subordinately and discriminatively (C. Brown \& Chin Roemer, 2016; Díaz McConnell, 2019; Mastro \& Behm-Morawitz, 2005; Menjívar, 2016; Moraga, 2018; Weaver, 2005).

Negi's statement about the different depictions of white and dark-skinned Puerto Rican girls in the film represents a critical reading of discriminatory discursive construction experienced by female subjects from the same country but with different skin colors. White Puerto Rican girls are placed in a better construction because they have Latin roots, so they sing sweet songs to Italian men who have genetic closeness. Meanwhile, negatively, darkskinned Puerto Rican girls are portrayed as behaving poorly by sleeping with their lovers. These two contrasts are discriminatory representations that are disseminated to the public through film, so that viewers will get stereotypical ideological messages about dark-skinned Puerto Rican girls.

Negi does not reject that many Puerto Rican women who sleep with their lovers follow American culture, but the visual construction through film can encourage the public to assume that Latin culture provides a respite for premarital sexual activity. The stereotype of Latin women in Hollywood films cannot be separated from the construction of sexuality such as prostitutes or subjects who have freedom in love relationships with the opposite sex as represented in the harlot, female clown, and dark lady (Berg, 2002, pp. 66-77). In fact, on the contrary, Puerto Rican people dislike of such sexual activity. In addition, what's even more annoying for Negi is that Puerto Rican girls are always portrayed as whores because of the way they dress. It is in contrast with the fact that she knows because most Latin girls are never allowed to wear a skirt that is above the knee. In this position, we see a criticaldiasporic subject, Negi, creating a discursive defense of his mother cultures. After all, her 
mother, Mami, always socializes the goodness of Puerto Rican culture in the family's domestic space, so that when massively all the good is negatively stereotyped, she naturally resisted. Cultural hybridity, thus, makes diasporic subjects at a critical level to carry out strategic essentialism that uses identity as a political-cultural force when encountering pressure from the dominant group, although she does not reject appropriation of the host culture.

By following the discipline of modern education in schools for the whites, Negi can struggle over her ideals of becoming a professional actress. She is also involved in the shows which give her some roles. The opportunity to become a professional actress is widely open. Gradually, Negi begins to experience some changes in her behavior and she knows her family may have difficulty in understanding her life to realize her ideals. However, being in a relationship with family can create psychological problems related to cultural choices. It means that the practices of mimicry and hybridity still leave the issue of appropriation by diasporic subjects to metropolitan culture must meet with a longing for local culture. In fact, this issue has become a space to continue negotiating Puerto Rican ethnicity. After presenting a theatrical performance in which Negi played the role of Virgin, she feels entrapped between her new life as a student and an actress in one side and her family life with the strong ties to the homeland in other side.

Immobile, I stood halfway between both, unable to choose, hoping the party wouldn't move one inch away from me and that my family would stay solidly where they were. In the end I stood alone between both, and when it was clear no one has missed me in the spirited gathering of actors and teachers, I ambled back to Mami and in a few minutes, we were on the train to Brooklyn. (Santiago, 2012, p. 145)

As diasporic subject, Negi does familiarize herself with American metropolitan tradition to gain her dreams. She, for example, often joins parties with her white friends at school as a part of socialization. Having a party becomes something common for American especially for youngsters. When she gets used to the party, Negi actually violated Puerto Rican norms more and more, even though she cannot completely escape. The family and all cultures in it are a private space that always puts Negi as a subordinate subject. Conversely, the celebrations at parties and the friendships with other young Americans are activities in the public space. The tension between these two spaces, although ideally said to be able to generate creative energy for diasporic subject, can also establish serious problems when she cannot overcome and regulate the in-betweenness. She feels "immobile," cannot move to one of the poles, family and free life. When she is about to enter fully into the world of young white people, she still feels a distance because even though she has struggled to be like his white friends, she is still 
positioned as a different Latin woman. Meanwhile, to return to completely Puerto Rican cultures, in fact, she has committed many violations.

In a critical phase that can bring up a claim for identity, the ethical awareness will give Negi a tendency to remember and reconsider what she has experienced in the host society. When she realizes that "no one is missed in the spirited gathering of actors and teachers," returning to Mami in Brooklyn is a cultural choice to return to a local authority in metropolitan life. Indeed, she has many opportunities to get life progress and become an economically independent woman. Meanwhile, mother is a traditional authority that can interfere with her efforts to become a developed woman with a lot of disapproval. However, what must be noted is that Negi does not intend to give up all opportunities to become professional. What she needs is an inner and spiritual commitment to the family authority, when in metropolitan life she does not find it. No matter how strong the influence of liberalism, the presence of mother and family for a young woman who feel warmth and affection will surely recall their inner consciousness to go home. In addition, the absence of friends who will miss her, further, convince Negi to return to Brooklyn in where she will meet again her mother, family, and Puerto Rican-ness.

Negi's return to Mami and family in Brooklyn is an affirmation of identity inbetweenness that gives space to the presence of Puerto Rican nationality in metropolitantransnational space. The family becomes a cultural place to return in the midst of all liberal efforts to achieve life's progress. Moreover, the existence of the family is a form of nationality that must still be maintained in the US' multicultural life which actually provides opportunities for the growth of culture and national identity without ignoring the ideal values of America such as respect for freedom and equality. In such a position, the choice to return to the family as a national representation is actually reminiscent of the importance of American life that should have respected other ethnicities and races, instead of perpetuating racial stereotyping and discrimination as a legacy of the slavery and colonial era. Further, the significance of the family as a cultural and national metaphor is a discursive characteristic of the literary formation of Puerto Rican women writers, both on the island and the mainland (Moreno, 2012). By coming back to the family, the diasporic subject is still involved in the sustainability of mother cultures, even though they have been mixed with her struggle to realize dreams. 
Therefore, Negi, on many occasions, begins representing her country and culture wherever she goes. She thinks that it will have a positive impact on dominant society and it will overshadow the negative stereotypes.

I took every opportunity to mention Puerto Rico and Puerto Ricans, even when the subject of conversation had nothing to do with ethnicity or culture. If I relieved their ignorance about me, maybe they would look at the next Puerto Rican who came through with respect rather than suspicion. (Santiago, 2012, p. 241)

The discourse of "being pride in Puerto Rican-ness" represented through Negi's actions is a literary effort to articulate the enthusiasm of most Puerto Ricans in viewing and positioning their subjectivity in the midst of metropolitan life. Although they have already gained the US citizenship and have long carried out the process of appropriating the host cultures, many diasporic people identify themselves with Puerto Rican cultures and nationality because of the historical process of racial discrimination that they experienced from the past to the contemporary periods (Gálvez, 2013; Loveman \& Muniz, 2007; Silver, 2016; Vargas-Ramos, 2013). Negi's affirmation of Puerto Rican identity is thus a discursive strategy to strengthen local subjectivity which must not be discarded in metropolitan life as well as the struggle to reduce discrimination against immigrants by the host community. Furthermore, the diasporic subject also reminds American society of the discriminatory actions against immigrants which actually betray liberalism itself. In other words, diasporic subject's ethical-critical awareness can be a way to carry out "a new civilizing mission" to Western societies who in the long history of colonial and post-colonial incarnate themselves as carriers of a civilizing mission.

The awareness of the family's importance also helps Negi in making significant decisions at the end of the story when she faces two choices: moving to Miami with her boyfriend, Ulvi, or staying with her mother and family in New York. She, again, must choose a quite difficult choice because it relates to two ideological principles quite decisive, namely celebrating absolute freedom by living with her lover without the marriage bond and undergoing some conservatism by living with his mother and family.

In all the time we'd been lovers, it had never occurred to me that l'd ever have to make such a choice. One day, Ulvi would return to Turkey; or to Germany; or to who knew, who cared where. It would be Ulvi who would leave my life, not Mami. Over the years of watching Mami, La Muda, my aunts and cousins as they loved, lost, loved again, I'd learned that love was something you get over. If Ulvi left, there would be another man, but there would never, ever be another Mami. (Santiago, 2012, p. 310) 
The important awareness of the mother's significant role in various possibilities in the future becomes the main force to remain with the family. Such critical rhetoric in her mind about who will be together and leave her in the future is the representation of rational thought and commitment to the family in solving complicated problems. Memory and understanding of the importance of a mother's presence in life and all of her achievements so far are the main factors that make her survive with the family.

Her courage to think that one-day Ulvi-with any reason-may leave her, but Mami will not do so, represents the independence of female diasporic subjects who dare to reiterate gender equality before men. Indeed, Negi does not reject the presence of man, but because the understanding of gender equality as one of feminism's ideological values makes her brave not to depend on him. This choice is at the same time a strategic meeting point between the family's wisdom and emancipatory struggle. Of course, Mami is also a perfect example of how she fought for the healing of her boy when her husband was not willing to go to the US. So, in her family, in fact, Negi can continue to gain strength as capital to become a true woman while continuing to negotiate Puerto Rican-ness, without forgetting the efforts to get progress in a super-dynamic life in the US. The issue of cultural identity in a hybrid framework, as such, does not stop at one final stage but continues in a variety of dynamics as well as tension, but it is the ethical-critical awareness that will form flexible subjectivity in the midst of the host society. It is impossible for Negi to return to Puerto Rican cultures completely because liberal values have become her ideological belief as a young woman. At the very least, the family and some parts of Puerto Rican cultures will be a sign that in the midst of American cultural hegemony, there is still a space for subjectivity strategy that remains different amidst the ongoing mimicry and hybridity process.

The complexity of hybridity involving unhomely conditions, racial discrimination, mimicry/mockery and appropriation of some dominant cultures, and negotiation of some parts of Puerto Rican cultures are narrative and discursive struggles of Santiago as a diasporic writer in American society to articulate cultural, economic, ideological and gender issues. Almost a Woman is a memoir that represents Santiago's life journey in the midst of the tension between the demand to maintain the Puerto Rican identity and the enjoyment of being Americanized. This problem, in fact, is also experienced by many young Puerto Ricans and other Latinos in the contemporary period. In an interview, Santiago explains: 
'It's really amazing that they've had the exact same experience I have, that they're feeling isolated, that they're having struggles with their families, where the families expect you to do both, to integrate into the society and the culture, and to learn English and get an education, but at the same time they don't want you to change. It's impossible! You cannot change it. The girls are having the same issues that I had about how do I dress, I can't be too sexy, because then they're going to think you're the hot tomato Latina, or do I dress like a Gap advertisement.' (Navarro, 2015, p. 229)

As many diasporic subjects living with a nuclear family, in-betweenness is a particular challenge and problem. The desire of parents, families, or traditional/national authorities for diasporic young people to do the two things at once-learning the host and mother cultures in a balanced manner without having to change their subjectivity-is a moral and cultural burden that they bear in academic and everyday life. In fact, parents are also aware of the importance of American cultures, but the fear of their children's identity changing makes them behaving conservatively. In the story, we encounter the discourse of tension between Negi and Mami/family in interpreting the issue of identity changing. Santiago's discursive offer to continue to advance the strategic achievements of the nuances of liberal in the life of the diasporic young people is her rejection of the insistence of conservative groups who imagine the still-powerful island cultures in the mainland. It is impossible to expect that diasporic young people will not change while in their daily lives they are accustomed to cultural encountering with the hegemonic host cultures which are quite interesting. What can be done then is hybridity strategy in which they are still willing to carry out a part of mother cultures in an essential-strategic manner so that they remain bound to original identity in a dynamic and flexible manner. Of course, they require family authority does not overly stifle their struggle liberally.

What worries Santiago too is the fact, diasporic people, however great they are mimicking metropolitan cultures, many residents of the host society continue to have stereotypical views, such as through the phrase "the hot tomato Latina" for women from Latin America. Tragically, in a different form, people in the country of origin also still consider diasporic subjects to be the subjects of being Americanized as much as they try to practice mother/local culture.

'Also, one of the big issues they bring up is this whole concept that you came here when you were fourteen or fifteen or three or whatever, and then you go to Colombia and they don't think you're a Colombian anymore. That somehow the contamination of American culture in American ground makes you less than the people who never left. And this is a very big problem for those of us who now can easily travel from wherever we live to wherever our families are, or where our ancestors lived. If we want to go back there and we're not welcome and we're in fact-challenged, our identity is challenged, very openly. 
It really does something to you, and you wonder: who am I, then?' (Navarro, 2015, pp. 229-230)

Diasporic subjects are in two-sided stereotyping-both from the host community and the homeland community_from which they will question their true identity, "who am, I, then?" So, for Santiago, as she constructs in her novel, there is no point in diasporic youths being forced or force themselves to carry out authentic culture as a whole because besides it will make them finding difficulties for social interaction in the host society. They will also continue to be seen as the contaminated Others, so their identity will be "challenged" by the authorities or communities in their homeland. In such a position, Santiago negotiates the ethical-critical awareness of the diasporic subjects as a strategy as well as the power to determine what diasporic subjects should do in the host society, namely to plot in the flexibility of hybrid identities, without having to force speaking of cultural purity and being able to optimize the potential they could do with the appropriation of liberalism.

\section{Conclusion}

Through this novel, Santiago, at least, places her personal subjectivity as a female writer who experiences many socio-cultural, economic, and political events, both in Puerto Rico and in the US, as a starting point for composing narratives that construct a discursive choice of diasporic individuals and communities as an ideological framework which affect their cognition, both in thinking and action. By becoming a hybrid subject, diasporic young people can make ideal achievements in life by using a mechanism that is run by the dominant subject, white American society that once ruled Puerto Rico. In this way, they can interfere with the establishment of knowledge which is used as a means of legitimizing power. Santiago described how Negi, for example, can speak English with a white American accent and is able to have professional skills as an actress. In this way, Santiago conveys her world view that it is not appropriate for the host community to view Latin women only from their physical appearance. Puerto Rican women can also make creative efforts to struggle over what they idealize. So, when Negi returns to her mother and family, the discourse she delivered is equality and recognition that should be given to diasporic people-both in terms of their intellectual and professional capacities and their local culture-because they are all mandates of liberalism that Western society believed.

In such a discursive position, through Almost A Woman, we argue-adopting Hurtado (2019) - that Santiago constructs a subversion of Puerto Rican conservative power which 
could fetter the development of the diasporic youth as well as the hegemonic power of the host community which, despite providing many opportunities for the diasporic subject to progress, still doing stereotyping and racial discrimination. Cultural hybridity enables diasporic subjects to position themselves, their thoughts, and actions in a flexible appropriation of metropolitan cultures and negotiation of mother cultures while reform themselves to fulfill the will and desire to progress. In the arena of white hegemonic power and liberalism that subordinate non-Western communities, the diasporic subject is constructed to have the ethical-critical awareness to mimic as well as to mock because they still undergo a part of local cultures. In addition, they can also provide a new vision of the local view in positioning women and young people who can actually make creative leaps to contest in metropolitan life.

\section{REFERENCE}

Aboul-Ela, H. (2004). Comparative hybridities: Latin American intellectuals and postcolonialists. Rethinking Marxism, 16(3), 261-279. https://doi.org/10.1080/0893569042000239271

Aka, P. C., \& Deason, L. M. (2011). Culturally and linguistically competent public services in an era of english-only laws. International Journal of Public Administration, 34(5), 291-306. https://doi.org/10.1080/01900692.2010.533925

Al Maleh, L. (2009). Anglophone Arab Literature: An Overview. In L. Al Maleh (Ed.), Arab Voices in Diaspora: Critical Perspectives on Anglophone Arab Literature (pp. 1-63). Rodopi.

Alves, A. (2012). Esmeralda Santiago-The power of memories in rewriting History. 49th Parallel, $19,1-25$.

Araujo Dawson, B., \& Suárez, Z. E. (2018). How does transnationalism affect the perceptions of discrimination among Dominicans, Puerto Ricans and Cubans? Journal of Human Behavior in the Social Environment, 28(2), 162-176. https://doi.org/https://doi.org/10.1080/10911359.2017.1342582

Ashcroft, B. (2001). Post-Colonial Transformation. Routledge.

Bennett, J., \& Jaradat, M. (2011). Adolescent Immigrant Education: It Is About More Than Learning English. Journal of Cases in Educational Leadership, 14(1), 25-47. https://doi.org/10.1177/1555458911404352

Berg, C. R. (2002). Latino Image in Film: Stereotypes, Subversion, and Resistance. University of Texas Press.

Bhabha, H. K. (1994). The Location of Culture. Routledge.

Brown, C., \& Chin Roemer, R. (2016). Local Television News in Salinas, California. Electronic News, 10(1), 3-23. https://doi.org/10.1177/1931243116628585

Brown, K. (2010). West side story read from below: Young Puerto Rican women's cultural readings. Communication Review, 13(3), 193-215. https://doi.org/10.1080/10714421.2010.502808

Canclini, N. G. (2005). Hybrid Cultures: Strategies for Entering and Leaving Modernity. University of Minnesota Press.

Clachar, A. (1997). Ethnolinguistic identity and Spanish proficiency in a paradoxical situation: The case of Puerto Rican return migrants. Journal of Multilingual and Multicultural Development, 18(2), 107-124. https://doi.org/10.1080/01434639708666307

Cohen, R. (2008). Global Diaspora: An Introduction, 2nd Edition. Routledge. 
Daponte, B. O. (1996). Race and ethnicity during an economic transition: The withdrawal of Puerto Rican women from New York City's Labour Force, 1960-1980. Regional Studies, 30(2), 151166. https://doi.org/10.1080/00343409612331349548

DaSilva Iddings, A. C., \& Katz, L. (2007). Integrating Home and School Identities of RecentImmigrant Hispanic English Language Learners Through Classroom Practices. Journal of Language, Identity \& Education, 6(4), 299-314. https://doi.org/10.1080/15348450701542306

Davine, L. (2016). “Could We Not Dye It Red at Least?”: Color and Race in West Side Story. Journal of Popular Film and Television, 44(3), 139-149. https://doi.org/10.1080/01956051.2016.1161585

Díaz McConnell, E. (2019). Numbers, Narratives, and Nation: Mainstream News Coverage of U.S. Latino Population Growth, 1990-2010. Sociology of Race and Ethnicity, 5(4), 500-517. https://doi.org/10.1177/2332649218761978

Echano, M. V. (2003). "Somewhere between Puerto Rico and New York": The representation of individual and collective identities in Esmeralda Santiago's when I was Puerto Rican and almost a woman. Prose Studies, 26(1-2), 112-130. https://doi.org/10.1080/0144035032000235846

English, B. (2013). A Cultural History of Fashion in the 20th and 21st Centuries, From Catwalk to Sidewalk (2nd Edition). Bloomsbury.

Estrella, M. L., \& Kelley, M. A. (2017). Exploring the Meanings of Place Attachment Among Civically Engaged Puerto Rican Youth. Journal of Community Practice, 25(3-4), 408-431. https://doi.org/10.1080/10705422.2017.1347844

Fuentes, R. (2020). English learners' appropriation of English language policy at a U.S. university. International Multilingual Research Journal, 14(3), 233-247. https://doi.org/10.1080/19313152.2019.1684422

Furqon, S., \& Busro. (2020). Hibriditas Poskolonialisme Homi K. Bhabha dalam Novel Midnight's Children Karya Salman Rushdie. Jentera: Jurnal Kajian Sastra, 9(1), 73-91. https://doi.org/doi: 10.26499/jentera.v9i1.494

Gálvez, A. (2013). Immigrant citizenship: neoliberalism, immobility and the vernacular meanings of citizenship. Identities, 20(6), 720-737. https://doi.org/10.1080/1070289X.2013.842475

Garzone, G. (2017). Food, culture, language and translation. Journal of Multicultural Discourses, 12(3), 214-221. https://doi.org/10.1080/17447143.2017.1364255

Gonzalez-Sobrino, B. (2018). Who's in conflict? Racialization of Puerto Ricans in relation to other Latinxs in the New York Times, 2010-2015. Ethnic and Racial Studies. https://doi.org/https://doi.org/10.1080/01419870.2018.1501504

Goode, J. (1998). The contingent construction of local identities: Koreans and Puerto Ricans in Philadelphia. Identities, 5(1), 33-64. https://doi.org/10.1080/1070289X.1998.9962608

Grace, D. (2007). Relocating Consciousness Diasporic Writers and the Dynamics of Literary Experience. Rodopi.

Guzzardo, M. T., Todorova, I. L. G., Adams, W. E., \& Falcón, L. M. (2016). "Half Here, Half There": Dialogical Selves Among Older Puerto Ricans of the Diaspora. Journal of Constructivist Psychology, 29(1), 51-65. https://doi.org/10.1080/10720537.2015.1016640

Hall, S. (2003). Who Needs "Identity"? In S. Hall \& P. Du Gay (Eds.), Questions of Cultural Identity (pp. 1-17). Sage Publications.

Hall, S. (2013). Cultural Identity and Diaspora. In P. Williams \& L. Chrisman (Eds.), Colonial Discourse and Post-colonial Theory: A Reader (p. . 392-403). Routledge.

Hernández-Acosta, J. J. (2017). Designing cultural policy in a postcolonial colony: the case of Puerto Rico. International Journal of Cultural Policy, 23(3), 285-299. https://doi.org/10.1080/10286632.2015.1043288

Holtzman, J. D. (2006). Food and memory. Annual Review of Anthropology, 35, 361-378. https://doi.org/10.1146/annurev.anthro.35.081705.123220

Hurtado, R. (2019). Decolonial Puerto Rican Women's Writings: Subversion in the Flesh. Palgrave Macmillan.

Hwang, S. S., Xi, J., \& Cao, Y. (2010). The conditional relationship between English language proficiency and earnings among US immigrants. Ethnic and Racial Studies, 33(9), 1620-1647. https://doi.org/10.1080/01419871003642375 
Ichijo, A., \& Ranta, R. (2016). Food, National Identity and Nationalism: From Everyday to Global Politics. Palgrave Macmillan.

Král, F. (2009). Critical Identities in Contemporary Anglophone Diasporic Literature. Palgrave Macmillan.

Ling, J. (1998). Narrating Nationalism: Ideology and Form in Asian American Literature. Oxford University Press.

Liu, A. H., Sokhey, A. E., Kennedy, J. B., \& Miller, A. (2014). Immigrant threat and national salience: Understanding the "English official" movement in the United States. Research and Politics, April-June, 1-8. https://doi.org/10.1177/2053168014531926

Lobo, A. P., Salvo, J. J., \& Hurley, D. (2012). The Confluence of Immigrant Ethnicity and Race in New York: A Socioeconomic Perspective. Journal of Immigrant and Refugee Studies, 10(1), 31-53. https://doi.org/10.1080/15562948.2012.646228

Lorrin, T. (2015). Puerto Ricans in the United States. In The Oxford Research Encyclopedia, American History (pp. 1-24). Oxford University Press. https://doi.org/10.1093/acrefore/9780199329175.013.32

Loveman, M., \& Muniz, J. O. (2007). How Puerto Rico became white: Boundary dynamics and intercensus racial reclassification. American Sociological Review, 72(6), 915-939. https://doi.org/10.1177/000312240707200604

Mallett, S. (2004). Understanding home: A critical review of the literature. Sociological Review, 52(1), 62-89. https://doi.org/10.1111/j.1467-954x.2004.00442.x

Mastro, D. E., \& Behm-Morawitz, E. (2005). Latino representation on primetime television. Journalism and Mass Communication Quarterly, 82(1), 110-130. https://doi.org/10.1177/107769900508200108

Matsuda, M. J. (1991). Voices of America: Accent, Antidiscrimination Law, and a Jurisprudence for the Last Reconstruction. The Yale Law Journal, 100(5), 1329-1407. https://doi.org/doi: $10.2307 / 796694$

Menjívar, C. (2016). Immigrant Criminalization in Law and the Media: Effects on Latino Immigrant Workers' Identities in Arizona. American Behavioral Scientist, 60(5-6), 597-616. https://doi.org/10.1177/0002764216632836

Menjívar, C., \& Bejarano, C. L. (2004). Latino immigrants' perceptions of crime and police authorities in the United States: A case study from the Phoenix Metropolitan area. Ethnic and Racial Studies, 27(1), 120-148. https://doi.org/10.1080/0141987032000147968

Mignolo, W. D. (2007a). Delinking: The rhetoric of modernity, the logic of coloniality and the grammar of de-coloniality. Cultural Studies, 21(2-3), 449-514. https://doi.org/10.1080/09502380601162647

Mignolo, W. D. (2007b). From Central Asia to the Caucasus and Anatolia: transcultural subjectivity and de-colonial thinking1. Postcolonial Studies, 10(1), 111-120. https://doi.org/10.1080/13688790601153198

Mignolo, W. D. (2011). Geopolitics of sensing and knowing: On (de)coloniality, border thinking and epistemic disobedience. Postcolonial Studies, 14(3), 273-283. https://doi.org/10.1080/13688790.2011.613105

Mignolo, W. D. (2020a). Coloniality and globalization: a decolonial take. Globalizations, $0(0), 1-18$. https://doi.org/10.1080/14747731.2020.1842094

Mignolo, W. D. (2020b). On decoloniality: second thoughts. Postcolonial Studies, 23(4), 612-618. https://doi.org/10.1080/13688790.2020.1751436

Mignolo, W. D., \& Walsh, C. E. (2018). On Decoloniality: Concepts, Analytics, Praxis. Duke University Press.

Miller, E. R. (2009). Orienting To "Being Ordinary": the (Re)Construction of Hegemonic Ideologies in Interactions Among Adult Immigrant Learners of English. In Critical Inquiry in Language Studies (Vol. 6, Issue 4). https://doi.org/10.1080/15427580903337446

Moraga, J. E. (2018). On ESPN Deportes: Latinos, Sport Media, and the Cultural Politics of Visibilities. Journal of Sport and Social Issues, 42(6), 470-497. https://doi.org/10.1177/0193723518797030 
Moreno, M. C. (2012). Family Matters: Puerto Rican Women Authors on the Island and the Mainland. University of Virginia Press.

Morton, S. (2007). Spivak: Ethics, Subalternity, and the Critique of Postcolonial Reason. Polity Press.

Moslund, S. P. (2010). Migration Literature and Hybridity: The Different Speeds of Transcultural Change. Palgrave Macmillan.

Navarro, M. (2015). A Writing Life: Esmeralda Santiago and Mireya Navarro in Conversation. Review (United Kingdom), 48(2), 226-233. https://doi.org/10.1080/08905762.2015.1083296

Oropesa, R. S., Landale, N. S., \& Greif, M. J. (2008). From Puerto Rican to pan-ethnic in New York city. Ethnic and Racial Studies, 31(7), 1315-1339. https://doi.org/10.1080/01419870701722521

Pérez, G. M. (2002). A tale of two barrios: Puerto rican youth and the politics of belonging. Souls, 4(3), 39-47. https://doi.org/10.1080/10999940290105291

Pousada, A. (2008). Puerto Rico, School Language Policies. In J. M. González (Ed.), Encyclopedia of Bilingual Education (pp. 701-704). Sage Publications. https://doi.org/10.4135/9781412963985.n267.

Ramos-Zayas, A. Y. (2004). Implicit social knowledge, cultural capital, and "authenticity" among Puerto Ricans in Chicago. Latin American Perspectives, 31(5), 34-56. https://doi.org/10.1177/0094582X04268445

Ramos-Zayas, A. Y. (2007). Becoming American, becoming black? Urban competency, racialized spaces, and the politics of citizenship among Brazilian and Puerto Rican youth in Newark. Identities, 14(1-2), 85-109. https://doi.org/10.1080/10702890601102555

Ramos, J. G., \& Daly, T. (Eds.). (2016). Decolonial Approaches to Latin American Literatures and Cultures. Palgrave Macmillan.

Reierson, S., \& Celedón-Pattichis, S. (2014). Transforming experience through english use and service-oriented cultural capital: Indigenous honduran immigrants to the U.S. Southwest. Latin American Perspectives, 41(3), 208-219. https://doi.org/10.1177/0094582X14524361

Rendon, M. (1974). Transcultural Aspects of Puerto Rican Mental Illness in New York. International Journal of Social Psychiatry, 20(1-2), 18-24. https://doi.org/doi:10.1177/002076407402000103

Ríos-Bedoya, C. F., \& Gallo, J. J. (2003). The association of alcohol use and depression among Puerto Ricans in the United States and in Puerto Rico. Journal of Ethnicity in Substance Abuse, 2(1), 1-13. https://doi.org/10.1300/J233v02n01_01

Rodriguez, M. E. (2013). Barriga Llena, Corazón Contento: Puerto Rican Women's Perspectives on Food, Identity, and US Influence on the Island [University of California]. https://communitydevelopment.ucdavis.edu/sites/g/files/dgvnsk1186/files/inlinefiles/Rodriguez_Maria.pdf.

Rolón-Dow, R. (2010). Taking a diasporic stance: Puerto Rican mothers educating children in a racially integrated neighborhood. Diaspora, Indigenous, and Minority Education, 4(4), 268284. https://doi.org/10.1080/15595692.2010.513258

Salkauski, J. (2013). Revolving Identity in Esmeralda Santiago's Almost a Woman. Label Me Latina/O, 3, 1-11. https://labelmelatin.com/wp-content/uploads/2013/08/Revolving-Identity-inEsmeralda-Santiago's-Almost-a-Woman.pdf.

Sambolin, A. (2015). The Phenomenon of Self-Translation in Puerto Rican and Puerto Rican U.S. Diaspora Literature Written by Women: The Cases of Esmeralda Santiago's América's Dream (1996) and Rosario Ferré's The House on the Lagoon (1995) from a Postcolonial Perspective [University of https://www.research.manchester.ac.uk/portal/files/54571373/FULL_TEXT.PDF

Santiago, E. (2012). Almost a Woman. De Capo Press.

Senreich, E. (2018). The Persistent High Rates of Heroin Use Among the Puerto Rican Population in the United States: A Qualitative Study. Social Work in Public Health, 33(7-8), 419-438. https://doi.org/10.1080/19371918.2018.1543626

Silver, P. (2016). "You don't look Puerto Rican": Collective memory and community in Orlando. Memory Studies, 9(4), 405-421. https://doi.org/10.1177/1750698015601179

Sohoni, D., \& Sohoni, T. W. P. (2014). Perceptions of immigrant criminality: Crime and social boundaries. Sociological Quarterly, 55(1), 49-71. https://doi.org/10.1111/tsq.12039 
Stock, F. (2010). Home and Memory. In K. Knott \& S. McLoughlin (Eds.), Diaspora: Concepts, Intersections, Identities (pp. 24-28). Zeds Book.

Stufft, D. L., \& Brogadir, R. (2011). Urban principals' facilitation of english language learning in public schools. Education and Urban Society, 43(5), 560-575. https://doi.org/10.1177/0013124510380720

Sutton, D. E. (2001). Remembrance of Repasts: An Anthropology of Food and Memory. Berg Publishers Ltd.

Suwondo, T. (2014). Kajian Wacana Sastra Pascakolonial dan Pembangunan Karakter Bangsa. Jentera: Jurnal Kajian Sastra, 3(2), 95-105.

Szalay, L. B., Canino, G., \& Vilov, S. K. (1993). Vulnerabilities and cultural change: Drug use among puerto rican adolescents in the United states. Substance Use and Misuse, 28(4), 327-354. https://doi.org/10.3109/10826089309039632

Tallapessy, A., Wahyuningsih, I., \& Anjasari, R. A. (2020). Postcolonial Discourse in Coogler Black Panther: A Critical Multimodal Discourse Analysis. Humaniora, 32(1), 75-87. https://doi.org/doi. 10.22146/jh.v32i1.47234

Tyson, L. (2006). Critical Theory Today, A User-Friendly Guide, 2nd Edition. Routledge.

Umaña-Taylor, A. J., \& Bámaca, M. Y. (2004). Immigrant mothers' experiences with ethnic socialization of adolescents growing up in the united states: An examination of colombian, guatemalan, mexican, and puerto rican mothers. Sociological Focus, 37(4), 329-348. https://doi.org/10.1080/00380237.2004.10571250

Urzúa, A., \& Gómez, E. (2008). Home style Puerto Rican: A study of language maintenance and use in New England. Journal of Multilingual and Multicultural Development, 29(6), 449-466. https://doi.org/10.1080/01434630802147999

Valkeburg, P. M., \& Piotrowski, J. T. (2017). Plugged In: How Meia Attract and Affect Youth. The Yale University Press.

Vargas-Ramos, C. (2013). Puerto Ricans: citizens and migrants - a cautionary tale. Identities, 20(6), 665-688. https://doi.org/10.1080/1070289X.2013.828619

Vargas-Ramos, C. (2014). Migrating race: Migration and racial identification among Puerto Ricans. Ethnic and Racial Studies, 37(3), 383-404. https://doi.org/10.1080/01419870.2012.672759

Vidal Claramonte, M. Á., \& Faber, P. (2017). Translation and food: the case of mestizo writers. Journal of Multicultural Discourses, 12(3), 189-204. https://doi.org/10.1080/17447143.2017.1339352

Vieira, E. R. P. (1999). Postcolonialisms and the Latin Americas. Interventions, 1(2), 273-281. https://doi.org/10.1080/13698019900510381

Walder, D. (2012). Postcolonial Nostalgias: Writing, Representation, and Memory. Sambalpur University.

Watson, J. (2013). Strategic autoethnography and American ethnicity debates: The metrics of authenticity in when i was puerto rican. Life Writing, 10(2), 129-150. https://doi.org/10.1080/14484528.2013.766124

Weaver, C. N. (2005). The changing image of Hispanic Americans. Hispanic Journal of Behavioral Sciences, 27(3), 337-354. https://doi.org/10.1177/0739986305278459

Weigui, Z. (2016). On the Search for Identity in When I was Puerto Rican. 6(8), 136-141.

Wright, C. L. (2014). Sexual Behaviors of Hispanic Emerging Adults: Examining the Immigrant Paradox. Marriage and Family Review, 50(3), 246-268. https://doi.org/10.1080/01494929.2013.879550

Wurzman, I., Rounsaville, B. J., \& Kleber, H. D. (1982). Cultural values of Puerto Rican opiate addicts: An exploratory study. American Journal of Drug and Alcohol Abuse, 9(2), 141-153. https://doi.org/10.3109/00952998209002618

Zavodny, M. (2000). The effects of official English laws on limited-English-proficient workers. Journal of Labor Economics, 18(3), 427-452. https://doi.org/10.1086/209965

Zhen, Y. (2016). English proficiency and earnings of foreign-born immigrants in the USA from 1980 to 2000: The effect of minority-language enclaves. Forum for Social Economics, 45(4), 329349. https://doi.org/10.1080/07360932.2015.1026920 